\title{
ВИЗИЯ ЗА ЛУДОСТТА В КОРПУС ОТ БЪЛГАРСКИ ЛИТЕРАТУРНИ ТЕКСТОВЕ В ПЕРИОДА 1894 - 1990 ГОДИНА
}

\author{
Веселин Веселинов \\ VISION OF INSANITY IN THE BULGARIAN LITERARY TEXTS \\ (1894 - 1990) \\ Veselin Veselinov
}

\begin{abstract}
Insanity fascinates novelists and poets, who weave it into their writing, in spite of its ever puzzling complexity. The literary works of the Bulgarian canonical writers shed light on the various types of mental health issues through topic variations and viewpoints in psychiatry and psychoanalysis. The article discusses some of the most iconic figures in the local classical literature such as Ivan Vazov, Kiril Hristov, Elin Pelin, Georgi Stamatov, Geo Milev, Aleksandar Vutimski, Aleksandar Gerov, Pavel Vezhinov, Ivan Radoev, Dobromir Tonev and Boris Hristov, trying to answer the question if their fiction definitions can moderate or depict psychotic disorders, drawing a relevant conclusion about the status of our knowledge of the etiology and meaning of schizophrenia.
\end{abstract}

Key words: classical Bulgarian literature, psychiatry, psychoanalysis, insanity

DOI: https://doi.org/10.46687/UNLY7910

\section{Предисловие}

А ако искаш да узнаеш повече за лудостта, възлез до мен и виж през процепа, от който Бог ни гледа, че всяко деяние човешко, освен служенето Нему, е налудно...

Борис Христов - „Спомени за хора, камъни и риби”

За лудостта като че ли не съществува базово знание в най-висш смисъл, по посока на единна, цялостна, философски „опакована” в познавателни рамки и постулати позиция, която да притежава интердисциплинарен характер. Макар да е проблем с общочовешко значение, тя все още е като уравнение с много неизвестни. Назряла е необходимостта от по-детайлно и най-вече дълбоко вглеждане в нейната феноменология, което да заеме средищно място в бъдещото ѝ широко тълкуване в колкото се може по-едри контексти, чрез интегриране и 


\section{Годишник на ФХH, XXXII A}

съгласуване на доказателства и информация от всякакви източници и концепти.

Понятието „психоза” бива обговаряно като „психична болест, съпроводена с дълбоки разстройства на душевността в по-тесен смисъл на думата"1 в психиатрията; като „сложно психобиологично заболяване, водещо до такава степен на дезорганизация, че човекът преживява основни промени в личността и големи затруднения в житейското си функциониране"2 в клиничната психология, а вглеждайки се и през окуляра на психодинамичната доктрина, откриваме дефиницията „нарцистична невроза”, характеризираща се с оттегляне на либидото навътре, резултат на значително смущение във връзката на аза с външния свят $^{3}$. Налице са и алтернативни, доста спекулативни гледища, като това на унгарския психоаналитик Майкъл Балинт ${ }^{4}$, с опйсания от него дефект на психичната структура в смисъла на „недостатьк” (необходимо условие за всяко заболяване), което пък се доближава до допускането на един от най-влиятелните френски интелектуалци Жак Лакан за наличие на „елементарен феномен”, в който се проявяват най-ранните фактори, определящи и отключващи страданието. Съществуват и съвсем крайни схващания: например австрийският учен Вилхелм Райх ${ }^{6}$ радикализира идеята за „дявола” като точен израз на шизофренната деформация на природата в човека. Като остро философски въпрос лудостта бива дефинирана „в нейната най-обща, но и най-конкретна форма” от Мишел Фуко ${ }^{7}$ по следния начин - „несъмнено нищо друго, освен отсъствие на дело".

${ }^{1}$ Вж. Panteleev 1992: 83-102 за характеристика на човешката личност при значителна част от душевните заболявания.

${ }^{2}$ Вж. Corsini 1998: 1427-1428 за материали, свързани с шизофрения и шизотипна личност.

${ }^{3}$ Вж. Froyd 2014: 244-252 за фундаментални различия между невроза и психоза.

4 Вж. Tome, Kehele 2009: 336-339 за теория за възникването на психични и психосоматични заболявания и терапевтично-техническата концепция за новото начало.

5 Вж. Wachsberger 2013: 126-127 за хипотезата за първоначално увреждане, предхождащо налудността.

${ }^{6}$ Вж. Rayh 2012: 504-511 за описание на термина „шизофренно разцепване”.

${ }^{7}$ Вж. Fuko, Derida 1996: 32-38 за необходимост от изработване на история на лудостта (структурално изследване на историческия ансамбъл - понятия, институции, юридически и полицейски мерки, научни концепти). 
Въобще са правени множество опити да се установи природата на явлението, изказвани са различни проникновени предположения в науката, но в никакъв случай не бива да се пренебрегва и ролята на художественото слово при откриването на големите истини. Дали те не са именно в голямата литература, чиито високи измерения значително да спомогнат да се обозрат основните пунктове на психозата като феномен? Пътят за изясняване на нейните особености би могъл да се опре на един обстоен анализ на употребите, мястото и изображението на понятието в контекста на фикционалното (който е и задача на настоящата разработка) чрез изграждане на мрежа от произведения, необходими за задълбочаване в тематиката до постигането на целта историческа справка за лудостта от литературна перспектива. Обект на изследването са прозаически и поетични родни текстове с ореола на нетленното, които очертават тематичната територия на менталното увреждане в националния културен канон. Следва да дефинираме и изградим работните хипотези, са откроени в следващите пунктове.

1. Предполагаме, че в зоната на книжовност от такъв калибър няма да фигурира строго разделение между физиологично и психично (така характерно за някои медицински теории ${ }^{8}$ ), що се касае до произхода и интервенирането на шизофренията. Представянето на личността би било дихотомно (като единство между душа и тяло).

2. Смятаме, че фокус в прозата не е толкова метафориката на лудостта (смелост, неистова жажда за свобода, борба и революция), колкото болезненият въпрос на етиката ${ }^{9}$, свързан с другостта (за отношенията на дръзналия да се опълчи срещу вкоренената в нашите земи традиция отделен човек с общността ${ }^{10}$, имайки предвид и социалните разломи в българската история). Дълбоката връзка между литература и епоха може да отговори на множество етични въпроси, свързани с психичните заболявания и начина, по който едно общество ги възприема и третира.

3. Очакваме, че с инструментариума на поетичното слово ${ }^{11}$, болестта ще бъде романтизирана, като образците в това поле (Гео Милев, Александър Вутимски, Иван Радоев и Борис Христов) биха тласнали

\footnotetext{
${ }^{8}$ Вж. Zapryanov 1966: 12-18 за връзка между нервна система и болест.

${ }^{9}$ Вж. Markova 2017: 119-133 за основания за респект на хора с ментални увреждания.

${ }^{10}$ Вж. Marinov 2010: 415 за връщане на болния в общността и социотерапия.

11 Вж. Freud 2017: 25-34 за психоаналитична интерпретация на въпроса откъде поета черпи сюжетите си.
} 


\section{Годишник на ФХH, XXXII A}

научните дирения в посока, доближаваща се до идеите на феноменолозите (напр. Томас Шаш) за отказ от категориите „болестно” и ,здраво”/ „абнормно” и „нормално” и възприемане на невротиците и психотиците не като телесно болни, а като „своенравни характери”12. Тук е мястото да упоменем негативната натовареност на термина „лудост” и стигмираните страдащи (напр. „Човекът в ьгъла”), които биха били поставени върху нова, правдива плоскост благодарение на лексиката от висок регистър и философското дискутиране, към което предразполага тя. Така или иначе, заблуждения и широко разпространени предразсъдъци могат да се преодолеят единствено чрез ярки внушения при съприкосновението с хуманни позиции, които да възпитават емпатия и способност да възприемаме отсрещния с различността му и в неговото многообразие. Тук е редно да си припомним и позицията на самия Платон за източниците на поетиката, а именно вдъхновението и лудостта (Pancheva, Licheva, Yanakieva 2007: 18-23). Той вижда процеса на творене като състояние на изстьпление, загуба на разум и липса на контрол налудна обзетост от музите, вакханически ентусиазъм, подтикващ към сътворяване на поезия.

4. Макар и поставено за обсъждане, търсенето на генеалогичните начала на страданието няма да бъде отразено разгърнато и ще остане въпрос, който да се разрешава в нашата съвременна книжнина за сметка на многообразната клинична картина на болестта (вж. Petrov 2010: 230-245 за богато, подкрепено с примери от практиката на велики учени описание на шизофренията) в класическата изказност на капиталните трудове.

Нека да отбележим, че поради форма̀та на статията, е практически невъзможно да включим в размишленията си цялата съществуваща до този момент българска класика със свои версии за психозата, както и липсата на авторови претенции за непогрешимост, меродавен поглед и оценъчен радикализъм. Но за по-голяма пълнота на картината споменаваме и няколко примера за шедьоври на човешката мисъл в световен мащаб, които тематизират душевната нестабилност чрез прелюбопитни въпроси и интимни възгледи: „Крал Лир” на У. Шекспир, „Идиот” на М. Достоевски, „Записки на един луд” на Н. Гогол, „Лудите” на П.-Ж. дьо Беранже, „Полет над кукувиче гнездо” на К. Киси, „Лудостта на Мая Сковрон” на А. Минковски, Дон Кихот де ла Манча”

\footnotetext{
12 Вж. Ratner 2010: 657-660 за възгледи на Шаш за психиатрията като институция.
} 
на М. де Сервантес, „Лудият” на Ш. Петьофи, „Всеки бяга след лудостта си” и „Гений и лудост” на Д. д'Амброзио, „Стъкленият похлупак” на С. Плат, „Психиатрична болница Творки” на М. Биенчик, „Събрани есета за шизофренията" на Е. Уанг и т. н. Прави впечатление, че лудостта е предпочетена и вмъкната още като заглавие на повечето чужди творби, за разлика от перото на нашите класици, които сякаш я избягват в този смисъл (с изключение на „Лудата” на Е. Пелин, „Лудият” на А. Вутимски, „Поема, написана там от един луд” на И. Радоев и донякъде КирилХристовата „Бездна. Изповед на един умопобъркан”). В най-новите ни духовни пространства това като че ли е преодоляно и в обозримото бъдеще (в следваща статия на автора по темата), обект на целенасочен анализ и размишления ще бъдат актуални произведения като „Лудост” на Калин Терзийски, „Шизофреничката” и „Заблудите на психиатьра” на Йордан Иванов, „Дали съм луд”, „Диагнози”, „Луда съм, Господи” и „Без диагноза” от стихосбирките „Свят за лудите” и „Кабинети за ближни” на Ники Комедвенска, „Лудница” на Мартин Карбовски, сборника с разкази „Хоризонтите на лудостта” на Донко Найденов, „Лудият Лука” на Емил Андреев и „Адвокатьт на лудите” на Владо Любенов.

\section{Научно тълкуване на творчеството}

Науката е безиенен склад, който не гине... Иван Вазов

Литературата и науката са важни съставки при формиране на интелектуалното поле на една нация. А екзистенциални въпроси се интерпретират най-добре през непреходните идеи на изкуството, особено що се касае до духовната вселена на всяка нация, с класическите модели на нейната традиция. Там ни очаква богата палитра от гледни точки към заобикалящите ни казуси, която да разшири погледа към тях или поне да поднесе ценни исторически знания. Значението на всяко такова наследство е не само естетическо и поучително, но и познавателно, стига то да бъде всестранно осмислено чрез литературни, предимно критични прочити.

Високохудожествените творби са своеобразни интелектуални ориентири за фундаменталните теми от нашия живот, а тенденциите са към доближаване на границите между фикция, философия и емпирика, към откриване връзката между литературен сюжет и научна проблематика, до постигане на универсална лексикална лаборатория, която да насочи към ново поле за размишление, изхождайки от идеята за 


\section{Годишник на ФХH, XXXII A}

литературата като продуктивен хоризонт на общуване (четена откъм и през психологическото), оказващ най-силно въздействие и внушение върху интелигентната аудитория, противопоставяща се на безкнижността.

До този момент броят на сериозните анализи на употребата на лудостта в наративната традиция не е чак толкова значителен за България, като най-голямо впечатление прави монографията на София Ангелова-Дамянова, озаглавена „Сънищата на разума: истории на лудостта в българската проза" (Angelova-Damyanova 2015), в която авторката си поставя за цел изграждането на цялостна концепция за лудостта в следосвобожденската проза. Тук са добавени няколко белетристични произведения, които не са разгледани в иначе проницателния труд на Дамянова, вмъкнати са и еталонни поетически образци, за да се допълни картината с възгледи на мислителите на родната словесност по темата и да се провери приложимостта на медицинските и психологически характеристики на заболяването към неговото творческо изобразяване.

Съпоставката на сходни, дори тъждествени идеи през призмата на този прецизен инструмент - литературата, спомага за направата и на големите обобщения и изводи, които да ни приближат до истината на моралните уроци и да очертаят следващите епистемологични пътеки, по които да поемем с осъзнат интерес и необходимост от по-конкретни ценностни ориентири. Темата би могла да има много и разнопосочни интерпретации, ракурси и нееднозначни отговори, принадлежащи едновременно на медицина, философия, изкуство, дори политика и т. н.

\section{Главни измерения на лудостта в духовните пространства на българската литература}

В края на краищата нима е толкова важно дали човек е луд, или нормален? Важното е да се усеша добре... Павел Вежинов - „Бариерата”

Съществена част от нравственото и образователно възпитание на неукрепналия дух на нацията и неоценим документ на времето, романът „Под игото”, дело на най-едромащабната фигура в нашата литература Иван Вазов, предлага своя собствена дефиниция за лудостта, която е с висок метафоричен регистьр. Бягството от стигмата „градски идиот” е осъществено до голяма степен чрез цялостното налагане на образа на душевно страдащия Мунчо, живеещ в неразградената 


\section{Веселин Веселинов. Визията за лудостта...}

предосвобожденска традиционна общност, която не си позволява да го сочи с пръст, нито да го изключи от своите редици (социална съвест). В редките случаи, в които се сблъскваме с някакви нюанси на неприемане (обръщения като „скот” и действия по посока отнемане на свободата напр. заключването като „някой бесен луд в кулата, до манастирската вратня"), става ясно, че те са продиктувани от чуждия, външния, от врага, тъй като повествованието броди през времето на османското владичество. Страдащият се превръща не само в нарицателно: „Мунчо викахме на градския луд” (Gospodinov 2014: 142), но и „гложди” въображението на поколения автори в концептуалните им търсения, като в по-актуални текстове често откриваме по нещичко от него (например у Вуча лудия в „Аз още броя дните” на Георги Бърдаров, у дядо Муар в „Аврамови хроники” на Стефка Венчева, а най-вече във Василко в „Щьркелите и планината” на Мирослав Пенков), доказателство за непреходната значимост и гарантираното художествено безсмъртие както на солидната творба, така и на героя. Изобщо в широкообхватното творчество на Вазов могат да бъдат забелязани основополагащи идеи за нови произведения, позовали се на вазовската традиция и дори идеология за лудостта, а осезаемото по-нататъшно „посягане” към тази вечна тема в нашата литература безспорно е и принос от присъствието на Мунчо в пробуденото ни духовно битие.

Лудостта в епохалния космос на „Под игото” сякаш е нормирана благодарение на мястото, което е отредено на „тоя луд” („,единственият човек, който се осмели да протестира") в патриархалната вселена, в белочерковната общественост. Макар и част от една уж маргинализирана прослойка, той в никакъв случай не е периферен персонаж в наратива, неговото присъствие сред останалите е пълнокръвно, изпълнено с дълбока символика. Същинската му поява в романа е с ,пеене, което приличаше на виене”, което пък напомня „ту на опело, ту на плачевно стенание”. Мунчо „влиза” гръмко в сюжета, за да го завърши също толкова категорично и шумно чрез лудостта си (противопоставянето, което тя му позволява, като единствен правдив начин личността да съхрани своето национално и човешко достойнство). Кривите и безобразни знаци с ръце, кълченето, въртенето на главата, изпулените очи, „едно диво, нечовешко измучаване”, „един звук непонятен, едно грозно и глухо мукане, като на затворено говедо или на звяр в гората", което после се обръща на „страшно хъркане” (в повестта „Чичовци”, където отново има отредена роля на Мунчо), които Вазов приписва на своя „лишен от съзнание” „нещастник”, донякъде се доближават до 


\section{Годишник на ФХН, XXXII A}

идеята за кататонната хиперкинеза (възбуда) (Piseva 2005: 232), която е част от клиниката на рядко срещаната болест кататонна шизофрения. Повтарящите се „неизвестно добре защо” викове „русс-и-ан” в психиатрията се разглеждат като „неологизъм”13 (напълно нова и неразбираема дума, най-често опит да се открие подходящ семантичен начин за израз на собствените преживявания, които са напълно извън нормата). Амбивалентността ${ }^{14}$, считана в науката за едновременното отрицателно и положително отношение спрямо даден обект, може да бъде разчетена в ,тоя лишен от разум поглед”, в който се смесват дружелюбност и удивление със страх, страхопочитание и култ - всичко това към главното действащо лице в романа, а именно Бойчо Огнянов. Щом го съзре, Мунчовата физиономия се озарява от блажена усмивка, очите му блясват от „непонятен и безсмислен възторг”. Предвид факта, че това оживление всъщност никак не е лишено от логика, ние постепенно се приближаваме до споменатото вече и защитавано от Вазов нормиране на лудостта, което неслучайно кулминира в самия край на „Под игото”, когато в градчето, по-пусто и мълчаливо от „парясано гробище”, „като един призрак” Мунчо прекрачва възприетата людска норма на покорство чрез своя отказ да се примири с несправедливостите и жестокостите, на които става пряк свидетел. Чрез този финал Вазов като хроникьор на събитията на своето време осъществява един своеобразен отказ от разбиранията за здрав разум на съвременниците си. Тази му позиция се затвърждава със същата категоричност и в „Павле Фертигът”, където едно „полугламаво, полулудо, незлобиво, пернато, често духовито, винаги весело под своите дрипави дрехи и жалка външност” момче, бива обрисувано като „по-свястно от много свестни”. Подобно на Мунчо, героят от разказа превъзхожда в нравствено отношение останалите в Хисаря, считани за нормални. Авторът не предлага решение на въпроса относно етиологията на проблема у своите страдащи герои, такова ще се появи в по-късни творби, в различен исторически и културен контекст.

Разбира се, лудостта в „Под игото” далеч не се изчерпва само с премеждията на Мунчо, тя е примесена и с метафората за възрожденското пиянство и безумство на българския народ (на места

\footnotetext{
${ }^{13}$ Вж. Popov 2012: 113-119 за изброяване разстройствата във формата (структурата) на мисленето.

14 Вж. Veselinov 2020: 111-112 за трактовка на четирите първични симптома на шизофренията на Ойген Блойлер.
} 


\section{Веселин Веселинов. Визията за лудостта...}

дефинирано като „самонадеяност”), всъщност един от конструиращите романа мотиви, смислово ядро, благодарение на което у нас отекват и до днес благословиите на бай Марко ,-- Кой знае? Лудите ако направят, лудите ще направят нещо...” и ,-- Лудите, лудите - те да са живи!...”.

Опирайки се на „Под игото”, с голяма вещина и с „величествената си духовна сила"15 Вазов построява и по-обемист текст, една от найразгърнатите си работи - „Нова земя”, в която лудостта не е водеща нишка, но отново се прокрадва на определени места. Тук тя е единствено кривване от социалните порядки, употребявана е и по адрес на Драга, на която принадлежи и репликата „Аз обичам лудите”. Жената като обобщен образ е наричана „вятърничава, направена от болни нерви”, което по някакъв начин разкрива по-консервативните порядки на следосвобожденска България и незавидната позиция на нежния пол в новото общество. Разбира се, усещат се препратки и към ,Чичовци”, тъй като ревът на Мачухонски, Филович, Голичев и Патев превръща лицата им в ,лица на луди” (досущ като „мукане”-то на Мунчо), а явяващият се и тук Боримечката констатира, че „бунтовете ги правят луди глави, затова и лудости стават”, което ни спомня главите „Пиянство на един народ” и „Пробуждане” от предходната епическа творба и служи като ориентир за тогавашните стойности.

Ако в премисления български проект за Възраждането на „Под игото” сме свидетели на запазено място за чудака, за различния (при това ключово), а в прясно освободената „Нова земя” погледът постепенно започва да се откъсва от него (героят вече носи белега на историческа пасивност и морална съзерцателност - свидетелство за несъответността между него и времето $\left.{ }^{16}\right)$, то в България след Първата световна война, изобразена в „Малкият Содом” на Георги Стаматов, нарушеното душевно равновесие се оказва оразличителна линия между страдащия и общността. Митя Абаров носи непоносимата болка и самота, набрана в окопите и плена (необходимо е критично уточняване дали тук не става дума за посттравматично стресово разстройство - ПТСР (Popov 2003: 2065), каквото би могло да се постигне при дообогатяването и развиването на статията с повече доказателства от текста, медицински източници и по-изчерпателни разсъждения в бъдеще), които се амалгамират с тесния за душата му простор на променената София (акултурация или

${ }^{15}$ Вж. Ivanova 2020: 4-8 за митологията около Вазовата личност.

${ }^{16}$ Вж. Igov 2010: 315-316 за новата романова формула на Вазов. 


\section{Годишник на ФХH, XXXII A}

инкултурация) и „избухват като бомба” в него, алиенирайки го и довеждайки до агресивни и автоагресивни прояви с летален изход ${ }^{17}$, резултат по-скоро от създаденото усещане за непотребност и ненужност в лишения от устои нов свят, отколкото от наличие на психотично страдание (в случая следва да допуснем все пак и хипотезата за повишена афективност ${ }^{18}$, водеща до засилване на автосугестията и активиране на основни за параноидното налудообразуване психологични механизми). Бих си позволил да дебатирам по посока на болест, настанила се по-скоро в микроклетките на семейството на героя, както и в обществените такива обаче. Връзката между дерайлиране на психиката, лудост и суициден риск ангажира по-късно съзнанието и на Павел Вежинов, за да се разгърне със специфична функция в прозата на Калин Терзийски в наши дни. В „Малкият Содом” Стаматов изповядва разбирането за „,изострени”, „,разклатени”, „изхабени нерви”, за загуба на представа за околното у капитана, за граждани, които етикетират завърналия се като „малко ненормален”. Повествованието свидетелства именно за такова закрепване на устойчиви епитети към психичното страдание, пропити със силно отрицателна конотация и символна натовареност, резултат от социалните недъзи (дехуманизация и перфидност): „Митя е болен. Аз приказвах с лекари...”, „Той страда от апатия, нищо не го интересува”, „Митя е егоист”, „представиха медицинско свидетелство от видни специалисти, че е луд.”, „Душата му се пречупи”... Абаров е противоречив и далеч по-сложен от Мунчо образ, но разликата се състои в това, че не успява да се опълчи докрай срещу уродливите канони на времето си, белязани от нравствен недоимък. За него като че ли с пълна сила важат Ботевите вопли „Свестните у нас считат за луди...”.

В още две от стоящите във фундамента на българската литература произведения про̀чита на лудостта преминава през социалните мерки, през все по-наболяващия казус с бунтарския жест на ,ярката индивидуалност" (Konstantinova 2021), съзряла трагиката и абсурдността на живота, пренебрегнала нормата, осмелила се да я прекрачи. Като колос на нашата поезия, вулканичният и метежен Гео Милев съумява да внуши най-убедително необходимостта от ревизия на обществените порядки, на цели глобални концепции (отечество и Бог), на националния характер изобщо благодарение на своя „побеснял и велик” поп Андрей в поемата

\footnotetext{
17 Вж. Dimitrov 2007: 13-54 за подробни теоретични обяснения на самоубийството.

18 Вж. Haralanova, Haralanov 2017: 22-24 за заслуги за вникване в афективните механизми на параноидните психози на Блойлер.
} 
„Септември”. Посред общия анонимен смут „сюблимният” лирически персонаж се извисява със своята самота, лудост и епическа смелост (един бъдещ по-задълбочен анализ на тази здрава и повтаряща се троична връзка в литературното изобразяване би могъл да поднесе интригуващи въпроси и отговори), останал „спокоен като гранит” пред лицето на смъртта, дори сам предизвикал я, загърбвайки индивидуалното в името на огромната обща кауза на социалната революция. Божият храм, преди място за литургии и ектении, разрушен от гранатата на лудостта при Гео Милев, пък бива разтърсен от „един странен нечовешки глас”, който прекъсва проповедта на стария свещеник в разказа „Лудата” на ваятеля на родната духовност Елин Пелин. Дръзналата да предизвика всеобщо смущение Илчовица в своя неуместен за черковните догми пристъп (,,лудата падна на пода, легна и започна бързо да шепне с тънките си сухи устни, които трепереха нервно...”) всъщност задава едни от неразрешените въпроси в това човешко измерение: за божията любов, за човешката правда, за смисъла от вярата (,,.. безучастно гледаха бледите образи на светците"), за съществуването на авторитетите и на Бог въобще (реално преосмисляне на очевидността и при Гео Милев). Безспорното интелектуално влияние на Елин Пелин се изразява и във факта, че той не е пропуснал да даде обяснение за състоянието на героинята си, търсейки неговите корени в една нескончаема мъка по изгубената чест на детето ѝ, както и изобразяване на емпатията чрез съпричастността на ужасените и умилени хора („Някои от жените плачеха”, „... тая грозна картина сякаш издигаше нов кръст на човешкото страдание и извикваше милост и странен уплах").

Съвсем друга е посоката на проблематизиране, избрана от изящния и много дълбок автор и нравствен бунтовник Кирил Христов в сполучливо наречения от него роман „Бездна. Изповед на един умопобъркан", част от по-голям, но неосъществен докрай замисъл да се създава литература извън остарелите мисловни схеми на тогавашната интелигенция. Лудостта бива редефинирана и преформулирана (,диво състояние") с бляскава виртуозност през собствената художествена призма и разпознаваем разсъдъчен почерк на популярния предимно с поезията си Христов. Още в предговора към революционното с естетическите си възгледи произведение, чрез мисъл на Фридрих Ницше като начален импулс, авторьт ни насочва към отличителните клинични характеристики на индуцираното налудно разстройство (Stoychev 2005: 


\section{Годишник на ФХH, XXXII A}

235), чийто корен открива в половите въпроси ${ }^{19}$ и по този начин значително разширява темата и донякъде се вдълбочава в нея благодарение на интереса си към по-философските измерения на живота. Така неговият луд диригент, търсещ цели семейства и родове, в които да върши сексуални подвизи, става помощник на лекарите и обуздава лудите в „прелестна лудница”, в „един цял град на умопобъркани”, състоящ се от „многобройни спретнати павилиони, пръснати в един разкошен парк". За първи път щрихирана по такъв начин в българската литература (макар действието в романа да не се развива в България), темата за институционализацията на психично болните ще бъде поподробно пресъздадена, при това в различни трактовки, от Вутимски, Вежинов, Геров, Борис Христов (най-ярко), а в новата ни литература предимно от Калин Терзийски в „Лудост” и „Разкажи ми”, от Елена Алексиева в „Свети вълк” и от Георги Господинов във „Времеубежище”. Творбата на Кирил Христов изобилства и от още твърде смели за времето си прозрения - например това за социалната регулация на сексуалното поведение (Bostandzhiev 2005: 204-205), за половия глад и промискуитета като причини за генезиса на недъга (,човек може да полудее както от полово въздържание, така също и от злоупотреба със сексуалността...”), за душевната разпокъсаност на всички страни и за хаоса ${ }^{20}$ на героя (подчертани още в полето на заглавието с изразителния потенциал на „бездна”-та), за прекрачването и на други обществени норми, като например ексхибиционизма, великолепно вграден и в образа на Голата Ана в съвременното произведение на Керана Ангелова „Елада Пиньо и времето”, където (за разлика от романа на Христов) са експлицитно заявени и трагичните релационни обстоятелства, що се касае до въпроса за етиологията на този вид ,полудяване”.

Лудницата, видяна от перспективата на друг фин мислител със забележителни духовни обеми, изглежда като място, диаметрално противоположно на истинския свят, нейният обитател живее „срещу света", усещането е за затвор в „безкрайната и пуста равнина, в олющената потъмняла лудница...". Така остро се вторачва в трагизма на болестта Александър Вутимски в лиричното си произведение „Лудият”, където дори през мерената реч е успял да засегне извечни въпроси, като например този за качеството на психиатричната грижа в страната (можем

\footnotetext{
19 Вж. Atanasov 2017: 67-68 за описание на частичните нагони (ексхибиционизъм, воайорство, мазохизъм и садизъм).

${ }^{20}$ Вж. Daco 2015: 378-381 за идеята за „разцепване на ума”.
} 


\section{Веселин Веселинов. Визията за лудостта...}

да установим разликата на „дивния мир” на „най-уредената може би лудница на Германия" при Кирил Христов, с описаното от Вутимски: „Студените решетки крият луд и стая прашна, малка и изцапана...”); за самотността и изолираността на хоспитализираните $(,, \ldots$ и сам се гърчи като звяр - и вие...”); за неразбирането и безразличието на околните (,,...протягайки ръцете си напразно от лудницата вънка към света”).

Топос и в интелектуалната проза на България - старото, печално здание със зарешетени прозорци, е единствен дом и средоточие на живота на Доротея в „Бариерата” („Аз само спя там, иначе през деня си ходя на работа. Стационарна съм, както те казват...”). Героинята е може би най-ерудитски описаната дотук страдаща, чийто драматичен вътрешен свят прокарва нови линии към дефиницията за болестта в нашата литература, на които се позовават по-нататъшни ключови обобщения и прозрения. Павел Вежинов стига до значителни висоти в обглеждането на заболяването, хуманистичните му послания са болезнено откровени и кънтят в правдивия начин, по който третира темата. Например той е каноничният автор, който вдълбава найубедително в наследствените фактори, изиграли роля в развитието на болестния процес ${ }^{21}$ (казус, засегнат от Димитър Димов и Борис Христов, а в актуалния обществено-културен дебат и от Георги Бърдаров), а „две много силни душевни сътресения" (героинята е свидетел на нелепата смърт на баща си, по-късно става и жертва на физическо посегателство) се оказват отключващ елемент. Според практикуващия лаканиански психоаналитик Дариън Лийдър повечето психотици всъщност така и не отключват психоза в живота си без моменти на срив или разпад, но пък в други случаи психозата избухва и то често по ужасяващ начин и с катастрофално начало (Liydar 2019: 239-271).

Незагубила своята актуалност и до днес (макар и създадена в един по-особен социален контекст), творбата на Вежинов ни изправя пред оплетена мрежа от обосновани подвъпроси, които ще се опитам да формулирам по следния начин: съществува ли такова усещане за психологическа преграда/ „бариера” между здравия и болния в смисъла на неспособност за приемане на близост със страдащо човешко същество („И все пак имаше някаква преграда между нас, която преди това не съзнавах. Може би вечната преграда на инстинкта към всяка болест, дори

${ }^{21}$ Вж. Hristozov 1983: 124-126 за роля на наследствената информация в етиологията и патогенезата на шизофренията. 


\section{Годишник на ФХH, XXXII A}

когато не е заразна. Може би...”) и как би могло да се дефинира най-точно то с терминологичен език, който да обхване цялата сложност на нещо толкова неординарно; приличат ли си действително писателите и психиатрите по това, че донякъде познават истинската сила на човешката душа едновременно с ужасяващата ѝ слабост („Те поне от време на време имат възможност да погледнат през дупките на стобора...”), и ако до такава степен се доближават, защо са малко опитите да се обвържат в духовно общуване литература и медицина в диалог помежду им, макар и лъкатушещ (,,... И двете имат за обект човека. И човешката душа, разбира се...”); къде се намира пречупната точка между интровертността на затворената личност (,рядко забелязвам какво става около мен”) и патогенното оттегляне на либидото от случващото се навън, навътре (,,То не ме интересува, не ражда нищо в душата ми, даже когато другите се прехласват от него...”), а също и каква е връзката между липсата на интерес у Доротея към символичните послания на хронотопа и описаното психопатологично разстройство (Popov 2012: 170). Така откроените питания заслужават своите философски осмислени отговори, основна цел на авторовото научно бъдеще, където биха могли да се потърсят и конвергенции в казуистиката на „Бариерата” (Доротея) и „Малкият Содом" (Абаров), които да ни насочат към по-уверено изброяване на възможните предикати на самоубийството.

За разлика от пристъпващата с „малко странна походка”, със „спокойно и чисто” лице, запазила своята привлекателност и чудатост Доротея, Мария - героинята на Димитър Димов в едно от най-знаковите му произведения - романа „Тютюн”, е превърната от неизлечимата си и тежка болест в „страшен призрак”, в „ужасно видение” с идиотска, тьпа и маниакална усмивка, в „окаяна човешка развалина”. В дълбокото си хуманно творчество, в чиято основа са човешките чувства, авторът въвежда съвършено новата, многоъглова интерпретация за грижата към болния като дълг (,Ти не трябва да я оставяш сега... Ти не можеш да я захвърлиш като парцал...”), за невидимите нишки, спояващи като фина паяжина симптомите в общата картина на шизофренията ${ }^{22}$ („Но този спомен се бльскаше и скачаше безпомощно с разбити останки от други спомени, с безредни асоциации и отломки...”; „Но пьтечката на мисълта свърши изведнъж пред пукнатина...”; „А после по незнаен път в съзнанието ѝ се появи отново абсурдната идея за величие и лицето ѝ пак

\footnotetext{
${ }^{22}$ Вж. Onchev 2020: 148-157 за клиника на шизофренията.
} 


\section{Веселин Веселинов. Визията за лудостта...}

замръзна в предишната си високомерна гримаса...”) и за драматизма в оценяването на лудостта с трагически възгледи (,...някаква механизирана кукла, която всеки миг можеше да падне”; ,...някаква ужасна прилика с лице на мъртвец, излязъл от гроба”; ,...трагични очи без мисъл и съзнание, безумни очи...”, „Животът на Мария умря. Нима има смисъл дългът към един автомат без съзнание?"). Общото между героините на Вежинов и Димов е музиката (също вплетена чрез образи и смисли в представянето на заболяването), но при Доротея тя е нешо като вътрешен концерт и чуване на нотите (,„...в главата ми е скрит малък транзистор...”), а при Мария е мост между живота преди и след появата на психотичното страдание (,Жълтеникавите мъртвешки ръце на болната се протегнаха и почнаха да удрят безразборно върху клавишите...”; „Тя усещаше недостатъците на свиренето си и съзнаваше някак учудено, че нито пръстите, нито краката, с които натискаше педалите, ѝ се подчиняваха правилно, за да предаде ония оттенъци в свиренето, които желаеше”). Димов остава ненадминат по висина и дълбочина, що се касае до психологизма на неговия авторитетен и мощен глас в българския литературен контекст, артикулирал и онагледил възловите трудности и перипетии, през които преминава страдащият.

Следва да почерпим духовен опит от един текст, за който никак не се говори в академичната мрежа. Той е дело на творец, оставил след себе си забележителна професионална и човешка следа - Александър Геров. Уверено можем да наречем неговото „Неспокойно съзнание” многопластова тъкан от дълбоко лични истории, тъй като тук не става дума за интуитивно разбиране на лудостта (както във вече коментирани произведения), а за споделен чрез прозорливи и пространни коментари опит от първо лице, за ,жива книга”. Геров осъществява бягство от затвора на старите идеи и развива нови, особено що се касае до представянето на т. нар. симптоми на предния план (Ivanov 1985: 16-18) върху литературен терен. Излизането извън традиционните модели и условности в тогавашните класически работи спомага за достоверното изложение на изпитанията на едно унизително човешко съществуване в общество, изгубило своите мирогледни ориентири. Автентичният анализ, допълнен с лична гледна точка, в която прозира почти непоносима откровеност (новелата се чете тежко), високият интелектуализъм и многообхватният литературен талант на автора правят така, че разказът да не звучи отстранено и информативно (както на моменти у Стаматов и Вежинов), а да личи дълбоката необходимост, която го е продиктувала. Много малко е изтъквана несравнимата роля на 


\section{Годишник на ФХH, XXXII A}

Геров като интелектуалец за България, но в контекста на това изследване тя не може да бъде премълчана, тъй като той ни предлага едва ли не свидетелска литература (сам считан за луд) с изконно личен характер и огромен смислов обем, която дообогатява значително погледа ни към лудостта. Позовавайки се най-вероятно на паметта си, той създава това значимо изповедно произведение - първоизточник, в което убедително е обрисувал например параноята ${ }^{23}$ : „Аз бях твърдо убеден, че са ме довели тук не за да ме лекуват, а да ме разследват..."; безизходицата и сепарацията на болния: „Аз бях просто един нещастен маниак, който търсеше начини да се освободи от властната мъка, от безизходния хаос, от самосъзерцаващия се ужас...”; задължителното или принудително лечение: „Вместо да ме отведат в къщи, тези хора отново ме заведоха в психиатрията, моето постоянно жилище"; приложението на трудотерапията за привеждането в „общоприетото душевно състояние, което хората наричат нормално”: „Да павираш една улица, да изработиш един детайл на струг, да заковеш една ограда...” и най-въздействащото обяснение за травмата, причинена от загубата на близките, която изпраща героя в „нова орбита”, неизвестна за него до този момент, в състояние на „странно вцепенение”, както и за отказа тя да бъде приета и преработена (обладаване от идеята за изкуствено съживяване на хора).

Единственото, което може би липсва в „Неспокойно съзнание”, е по-предметно оконтуряване на психиатричната клиника със специалистите в нея, които полагат ежедневни грижи за нуждаещите се, на взаимоотношенията лекар - болен (в обсега на вниманието пък на Вежинов, който убедително изгражда диалектическата природа на връзката между доктор Юрукова и нейната пациентка Доротея). При Геров останалите обитатели на лудницата са анонимни, като започнем от пациентите: „... по леглата около мен лежаха хора, които говореха за шпионаж, за вредителство, за саботаж и за разни любовни приключения...”, за да стигнем до персонала: „Милосьрдните сестри...”, „Още когато показах среден пръст на санитарите...”, „брадатите професори” в този „сьвършено нов свят, коренно различен от реалния и все пак с всички елементи на реалност". Това е ключов в творбата елемент, който би могъл да се обясни с шизофренната празнота и опустошаване (Mentzos 2002: 90-91) - външният свят е изгубил своята

${ }^{23}$ Вж. Ivanov, Koychev 2018: 16-25 за налудност и налудообразуване при параноя и други психози. 


\section{Веселин Веселинов. Визията за лудостта...}

атрактивност и ценност. Специализираната болнична помощ (Shishkov 2005: 389) е по-скоро уклончиво интерпретирана, дори негативно нюансирана.

Напълно новият маниер на фабулиране, който демонстрира Борис Христов, позволява за пръв път в писмените следи на България да се акцентира върху цялостно образно изображение на терапевтичното общество, на трудовата дейност в него, на деонтологичните аспекти в психиатрията (Stoychev 2005: 391-393). В своята повест „Долината на обувките" Христов провежда директни уроци по човеколюбие, изграждайки неповторимия свят и вътрешен живот на едно не съвсем затворено пространство на лудостта, в чийто център е поставен Йорго. Благодарение на този персонаж изследваме множество незасегнати до тогавашния момент в литературата аспекти на клиничното страдание (то само по себе си е една от важните точки в цялото творчество на автора, със силен афинитет и интерес към него - напр. в „Смъртни петна” и „Спомени за хора, камъни и риби”). Промислено през по-различния ьгъл на нестандартния светоглед и критичния ум, подтикващ към сериозно вдълбочаване с многомерността на всяка лансирана идея, заболяването е вплетено в изкуство от много висока проба, далеч от догматичните четива. Второ мъжко отделение, този истински дом на „братството” на болните, който приютява Йорго след дълъг разпит, целящ да изясни клиничната картина и причините за неговото поведение, е представено чрез портретирането на работещите в него, които имат важна роля в живота на пациентите: доктор Матеев, сестра Павла, пазача Видо (видял Христос, облечен в сини дрехи, който му проговорил, изпращайки го да работи в Долината, при неговите болни „деца”), санитаря Тушо, готвачката Кана. Техните терапевтични, административни и координиращи задачи оформят представата за мултидисциплинарна екипност, необходима за осигуряване на по-достоен живот в болницата за активно лечение, а изграждането на йерархия в нея, с обособено място за всеки един, дава усещането за сигурност и полагане на грижа. В поновата българска литература също присъстват подобни примери, както е в „Аз, графинята” на Раймонд Вагенщайн и Петьр Попзлатев - тяхната Сиси среща разбиране и подкрепа от персонала на клиниката в Суходол и дори избира подредеността там пред кучешкия живот и анархията на действителността, а вече Калин Терзийски в „Лудост” осъществява истинска хуманитарна революция с най-органичните описания на психиатричната болница, облечени с изразните средства на прозата. 


\section{Годишник на ФХH, XXXII A}

У главния герой в „Долината на обувките” ние допускаме развитие на парафренен синдром ${ }^{24}$, тъй като мислите му се въртят около един фантастен сюжет, описван най-често в специализираните изследвания като „подготовка за полет в космоса”. В очите на „нормалните” Йорго е „човек с объркана граматика“, той рисува летящи тела, небесни платноходи и реактивни талиги, представя проект за асансьор към космоса, поместен в тръба, твърди, че притежава цветен слух и си има Екзюпери за домоуправител. В кухнята на отделението той отказва да се храни, вярвайки, че му дават разреден латекс, гума и отпадъчни остатъци от хирургията, което преодолява постепенно с майчинското покровителство на готвачката Кана. Авторьт засяга още медикаментозното лечение и неговия ефект върху симптомите, сугестията като средство в терапията, мястото на страдащия сред себеподобните в клиниката - Дибич, Делфина, Въжаря и Ушаков. Като мисионер в родната литература, при това с научна точност, Христов се спира и върху вътреутробния живот на своя герой, върху патологичната ранна връзка с майката и бащата Сарафко ${ }^{25}$, давайки ни възможност да предположим и една вродена уязвимост, онагледява сложното детство по отношение на сиблинговата тревожност, както и драматичния училищен живот на Йорго. Авторът засяга нарушенията в сексуалното му функциониране чрез юношеската му връзка с Теснолинейката Асиа и завършва тази благодатна за бъдещи психоаналитични тълкувания и неизследвана още в този аспект творба с любовта към натрапливата пациентка Лета, с която на финала поемат заедно към „страната на разума”. При подобен тип богата литература с особено, честно и смело писане няма как да не се влезе в дълбочини, които да открият пред нас необходимостта да се отворят художествените текстове с техните емоционални регистри за нов и внимателен прочит, за още гледни и отправни точки към медицината и психологията, особено в тяхната практическа зона.

Борис Христов има своя индивидуална траектория и на сериозен поет в националната ниша, из която „надничат” главите на изгубили своя ум провинциални луди, които извикват у нас една особена симпатия. В

24 Вж. Veselinov 2020: 173-176 за описание на мащабно проучване на Стоянов и Лупандин в сферата на парафренията.

${ }^{25}$ Вж. Laplansh, Pontalis 2014: 201-202 за техника от психотерапията на психозите, чиято цел е да създаде между терапевта и пациента отношение, аналогично с това на една „добра” майка към нейното дете. 


\section{Веселин Веселинов. Визията за лудостта...}

„Честен кръст”, например, оприличава поезията на стрела, с която лудият напада разума, доближавайки се по този начин до философските идеи в един от диалозите на Платон - „Федър”, а именно, че никой поет не може да се надява да отвори вратите на поезията, ако не е луд. В лиричната си творба „Човекът в ъгъла” Христов ни насочва към цяла гама от страдания, през които преминава отхвърленият: „Какво, че е с приведени крила, с тьга в очите...", които го белязват, отличават го от масата. Героят като че ли предпочита себе си пред света (Stankov 2015: 346), той разговаря с мухите, спейки се сражава с бога на съня или се е вторачил в издълбаната от сълзите му дупка, но етичното послание на поета е за нежност, търпение и разбиране, за търсене по-скоро на сходствата, отколкото на полемиката, за заличаване на границите между норма и патология: „... нали и той пристигна от брега, където нашто детство се удави, нали и той е като нас от слънце и от кал замесен...". За да завърши с навяващия тъга въпрос от „Мравките пеят”: „И къде е с хармоника през площада да мине лудият, а след него да звънка детския кошер”.

Визията за лудостта в поетиката на друго голямо име в културната памет на родината и самобитен мислител - Иван Радоев, е като че ли двуобразна: от една страна, лирическият човек е представен с неговия колорит, с особената символика на актьор в абсурдния театьр, с реквизит от сламена шапка, точен часовник, чадър и две цигари в устата в словесното пространство на „Отплуване” (самият Радоев счита поезията за преработване на хаоса в мечта). Лудият е и ,болна звезда, паднала от дървото небесно", която с увереност твърди за себе си, че е параход. Именно чрез образа на заминаващия параход Радоев очертава границите между двата свята - налудния и онзи, на избиращите сигурността на брега: „После параходът отплува. Ние оставаме на брега, изпратили себе си. Незаминали". Отворен в стихотворението остава въпросът къде всъщност е нормалният разум, но поетът по-късно ни ,завещава” отговора чрез нравствената си позиция: „Лудост не значи ненормалност. Тъкмо обратното” (Radoev 2019: 144). В „Поема, написана там от един луд” обаче романтичната окраска е ограничена единствено до „Душите на лудите спят в памука”, а метафората за лудостта е пренесена върху мащабния терен на времето и държавата, в които живеем (може би и до днес, макар творението да се появява през 1990 г.) с отчуждението, страданието, абсурда и липсата на човечност. Интересен е похватът, използван от поета - един индивидуален рисунък - чрез характерния за абнормността „летеж на идеи"/ fuga idearum (Popov 2012: 111) да изобрази фрагментарността и ужаса на действителността, което отново е 


\title{
Годишник на ФХH, XXXII A
}

размиване на границите между норма и болест, своеобразна парейдолия на съществуването.

В „Страх” на Борис Христов измерението на лудостта е съвсем същото - там болни са пастирите, на които човешкото паство се кланя, те са „по-малки от лешника”, заради тяхната лудост от небето вали барут свидетели сме как при формирането на интелектуалното поле на нацията двата полюса (този на Вазовското минало и настоящето на Прехода) се отдалечават неимоверно и от лудостта като героично пиянство на цял народ няма и следа, заменена е от намушканата държава с изтеклите градове и села (Иван Радоев) и останалата без сили, издъхваща земя (Борис Христов). И примиренческата позиция, липсата на жест тук и сега, като контрапункт на бурята, на революционното кипение, се оказва може би по-страшна лудост и от умственото опиянение.

\section{Заключение}

\author{
Разсъдъкът бавно разпръскваше \\ полумрака на лудостта... \\ Димитьр ДИМОВ - „Тютюн”
}

Изхождайки от представата за дидактичната роля на литература, бе направен опит за изложение на съществуващите употреби на лудостта в произведения, изграждащи панорамата на българския духовен свят, с цел да се отговори на големия въпрос, заложен в анотацията, за възможността на литературните понятия да обозрат и проумеят поне част от многоликата лудост. Възгледите и тезите на разглежданите автори са подложени на една критическа реоценка, ръководена от научни парадигми и достижения, като творбите са обект на аналитикоинтерпретативни наблюдения. Позовавайки се на тях, можем да постановим, че художествените описания на лудостта попадат в няколко категории и укрепват няколко концепции - например потвърждава се издигнатата във въведението хипотеза за представянето на болестта предимно в аспекта на затруднените взаимоотношения и това е за сметка на биологичните предразполагащи фактори (които се срещат предимно у Вежинов, Димов и Борис Христов), докато отключващите и поддържащи такива, са по-убедително застьпени (Стаматов, Геров, Кирил Христов, Елин Пелин). Действително е налице и известно романтизиране на образа на лудия в естетическото поле на стихотворните късове (Гео Милев, Александър Вутимски, донякъде при Иван Радоев и Борис Христов), но погледът е обърнат и към остра, реалистична мерена реч, която 


\section{Веселин Веселинов. Визията за лудостта...}

заклеймява като лудост въобще ситуацията, в която е поставен българинът след 1989 година.

Разбира се, изразена е готовността на автора за бъдещи разширени проучвания в същата сфера (например с допълнение принципите на диаболизма, където законите на нормалното поведение са изкривени до неузнаваемост), провокирана и от множеството въпроси, които възникват на база събраните дотук сведения: може ли да бъде подкрепена с още примери и съответно философски онагледена и обяснена установената неразривна връзка между понятията „лудост”,„самота”/,смелост” в значителен брой прозаически, но и лирически текстове; достатъчно богата ли е класическата българска поезия, за да предостави поетика, занимаваща се тясно с интересуващия ни проблем и неразкритите му нюанси; възможно ли е популяризиране на психоаналитичната теория (защо не и практика) в България, следствие от задълбочен психодинамичен прочит на корпус от съответните текстове с оригинална изказност („Малкият Содом”, „Бариерата”, „,Бездна”, „Тютюн”, „Неспокойно съзнание”, „Долината на обувките” и др.); какви метаморфози претьрпява лудостта от модерна литературна перспектива (след Иван Радоев и Борис Христов) и как са формулирани и съответно разрешени нейните проблеми в съвременното творчество.

\section{ИЗПОЛЗВАНА ЛИТЕРАТУРА}

Angelova-Damyanova 2015: Angelova-Damyanova, S. Sanishtata na razuma: istorii na ludostta v balgarskata proza. Burgas: Libra Skorp [Ангелова-Дамянова, С. Сънищата на разума: истории на лудостта в българската проза. Бургас: Либра Скорп].

Atanasov 2017: Atanasov, N. Teorii za psihichnoto razvitie v psihoanalizata. Sofia: Nov balgarski universitet [Атанасов, Н. Теории за психичното развитие в психоанализата. София: Нов български университет].

Corsini 1998: Corsini, R. Entsiklopediya po psihologiya. Sofiya: Nauka i izkustvo [Корсини, Р. Енциклопедия по психология. София: Наука и изкуство].

Daco 2015: Daco, P. Fantastichnite pobedi na modernata psihologiya. Sofia: Colibri [Дако, П. Фантастичните победи на модерната психология. София: Колибри].

Dimitrov 2007: Dimitrov, I. Detsa i yunoshi v kriza. Sofia: Prosveta [Димитров, И. Деца и юноши в криза. София: Просвета].

Doynov, Stankov 2015: Doynov, P., I. Stankov. „Tihata lirika” v balgarskata literatura. Sofia - Veliko Tarnovo: Kralitsa Mab [Дойнов, П. И. Станков. „Тихата лирика” в българската литература. София - Велико Търново: Кралица Маб]. 


\section{Годишник на ФХH, XXXII A}

Froyd 2014: Froyd, Z. Psihologiya na nesaznavanoto. Sofia: Colibri [Фройд, 3. Психология на несъзнаваното. София: Колибри].

Froyd 2017: Froyd, Z. Izkustvo i literatura. Sofia: Colibri [Фройд, З. Изкуство и литература. София: Колибри].

Fuko, Derida 1996: Fuko, M., J. Derida. Ludostta. Sofia: Kritika i Humanizam [Фуко, М. Ж. Дерида. Лудостта. София: Критика и хуманизъм].

Gospodinov 2014: Gospodinov, G. Nevidimite krizi. Sofia: Zhanet 45 [Господинов, Г. Невидимите кризи. София: Жанет 45].

Haralanova, Haralanov 2017: Haralanova, E., S. Haralanov. Emotsii i shizofreniya. Nov podhod kam afektivnostta pri ,neafektivni” psihozi. Sofia: Iztok-Zapad [Хараланова, Е., С. Хараланов. Емоции и шизофрения. Нов подход към афективността при „неафективни” психози. София: Изток-Запад].

Hristozov 1983: Hristozov, H. Detska psihiatriya - II preraboteno i dopalneno izdanie. Sofia: Meditsina i fizkultura [Христозов, Х. Детска психиатрия II преработено и допълнено издание. София: Медицина и физкултура].

Igov 2010: Igov, S. Istoriya na balgarskata literatura. Sofia: Ciela [Игов, С. История на българската литература. София: Сиела].

Ivanov 1985: Ivanov, V. et all. Diferentsialna diagnoza na psihichnite zabolyavaniya. Sofia: Meditsina i fizkultura [Иванов, В. (и съавт.) Диференциална диагноза на психичните заболявания. София: Медицина и физкултура].

Ivanov, Koychev 2018: Ivanov, V., G. Koychev. Paranoya i paranoyalni sastoyaniya. Sofia: Geya-Libris [Иванов, В., Г. Койчев. Параноя и параноялни състояния. София: Гея-Либрис].

Ivanova 2020: Ivanova, M. Vazov v podrobnosti. // Kultura, vol. 6 [Иванова, М. Вазов в подробности. // Култура, бр. 6].

Konstantinova 2021: Konstantinova, E. Obrazat na ludiya v balgarskata proza. // Artforum Archive $<$ https://www.angelfire.com/ar/artforum/archive/ af43/af43-44.htm (status 12.11.2021) >.

Laplansh, Pontalis 2014: Laplansh, J., J. Pontalis. Rechnik na psihoanalizata. Sofia: Colibri [Лапланш, Ж., Ж. Понталис. Речник на психоанализата. София: Колибри].

Liydar 2019: Liydar, D. Kakvo e ludostta. Sofia: Centar za psihosocialna podkrepa [Лийдър, Д. Какво е лудостта. София: Център за психосоциална подкрепа].

Marinov 2010: Marinov, P. Shizofreniyata. Sofia: ASYA - Rosen Mladenov [Маринов, П. Шизофренията. София: Ася - Росен Младенов].

Markova 2017: Markova, A. Dostoynstvo i choveshki sposobnosti. Veliko Tarnovo: Faber [Маркова, А. Достойнство и човешки способности. Велико Търново: Фабер].

Mentzos 2002: Mentzos, S. Psihodinamichni modeli v psihiatriyata. Varna: Steno [Менцос, С. Психодинамични модели в психиатрията. Варна: Стено]. 


\section{Веселин Веселинов. Визията за лудостта...}

Onchev 2020: Onchev, G. Kultura i psihopatologiya. Antropologiya na psihichnata bolest. Sofia: Riva [Ончев, Г. Култура и психопатология. Антропология на психичната болест. София: Рива].

Pancheva, Licheva, Yanakieva 2007: Pancheva, E., A. Licheva, M. Yanakieva. Teoriya na literaturata. Ot Platon do postmodernizma. Sofia: Colibri [Панчева, Е., А. Личева, М. Янакиева. Теория на литературата. От Платон до постмодернизма. София: Колибри].

Panteleev 1992: Panteleev, D. Literaturno tvorchestvo i shizofreniya. Sofia: Seva trading [Пантелеев, Д. Литературно творчество и шизофрения. София: Сева -трейдинг].

Petrov 2010: Petrov, K. Ludost i evolyutsiya. Sofia: Iztok-Zapad [Петров, К. Лудост и еволюция. София: Изток-Запад].

Piseva 2005: Piseva, D. et all. Psihiatriya. Sofia: Arso - Asen Petrov [Писева, Д. (и съавт.). Психиатрия. София: Арсо - Асен Петров].

Popov 2003: Popov, H. Posttravmatichen stres. Psihosocialni perspektivi i krizisnoterapevtichni interventsii. Sofia: Lik [Попов, Х. Посттравматичен стрес. Психосоциални перспективи и кризисно-терапевтични интервенции. София: Лик].

Popov 2012: Popov, G. Psihopatologiya. Fenomenologiya. Metodologiya. Varna: Steno [Попов, Г. Психопатология. Феноменология. Методология. Варна: Стено].

Radoev 2019: Radoev, I. (i naslednitsi). Prigotvi se da nyamash. Sofia: Akvarius [Радоев, И. (и наследници). Приготви се да нямаш. София: Аквариус].

Ratner 2010: Ratner, Y. Psihoanaliza. Klasitsite. Sofia: Kibea [Ратнер, Йоз. Психоанализа. Класиците. София: Кибеа].

Rayh 2011: Rayh, W. Analiz na haraktera. Sofia: Lege Artis [Райх, В. Анализ на характера. София: Леге Артис].

Tome, Kehele 2009: Tome, H., H. Kehele. Uchebnik po psihoanalitichna terapiya N1. Sofia: Nov balgarski universitet [Томе, X., X. Кехеле. Учебник по психоаналитична терапия. София: Нов български университет].

Veselinov 2020: Veselinov, V. Longitudinalno prosledyavane na sluchay $v$ uchilishtnoto prostranstvo - hipoteza za visok risk ot razvitie na parafrenen sindrom. - In: Godishnik na Sofiyskiya universitet, Filosofski fakultet. Kniga doktoranti, N 4, Sofia: UI „Sv. Kliment Ohridski“ [Веселинов, В. Лонгитудинално проследяване на случай в училищното пространство хипотеза за висок риск от развитие на парафренен синдром - B: Годишник на Софийския университет, Философски факултет. Книга докторанти, 4, София: УИ „Св. Климент Охридски“]].

Veselinov 2020: Veselinov, V. Teoretichen obzor: sreshta mezhdu fundamentalni psihiatrichni (nozologichni) otkritiya i psihodinamichni kontseptsii v sferata na detsko-yunosheskata psihoza. - In: Doktorantski cheteniya. Sbornik s dokladi. Sofiyski universitet. Filosofski fakultet. Sofia: UI „Sv. Kliment 


\section{Годииник на ФХН, ХXXII A}

Ohridski“, s. 109-130 [Веселинов, В. Теоретичен обзор: среща между фундаментални психиатрични (нозологични) открития и психодинамични концепции в сферата на детско-юношеската психоза B: Докторантски четения. Сборник с доклади. Софийски университет „Св. Климент Охридски“. Философски факултет. София: УИ „Св. Климент Охридски“, с. 109-130].

Waysberger 2013: Waysberger, H. Ot elementarniya fenomen do prezhivyavaneto za zagadachnost. - In: Lacan J., J-A. Miller, E., Laurent, H. Waysberger (eds.). Psihozite. Sofia: Siela [Вайсбергер, Х. От елементарния феномен до преживяването за загадъчност. - В: Лакан, Ж., Ж-А. Милер, Е. Лорен, Х. Вайсбергер (съст.). Психозите. София: Сиела].

Zapryanov 1966: Zapryanov, T. Razgovor s nevrologa. Plovdiv: Hristo G. Danov [Запрянов, Т. Разговор с невролога. Пловдив: Христо Г. Данов]. 